\title{
Taras Lyuty
}

\section{IDEOLOGICAL INTERPRETATIONS OF NIETZSCHE'S PHILOSOPHICAL VIEWS IN THE UKRAINIAN CULTURAL CONTEXT (THE END OF THE $19^{\mathrm{TH}}-$ BEGINNING OF THE $20^{\text {TH }}$ CENTURIES)}

\section{Introduction}

The current state of the Ukrainian reception of Nietzsche is only at its dawn. This is evidenced by the lack of the relevant studies of the leading dominants of his philosophy. Nietzsche's controversial heritage is almost unreachable for the Ukrainian-speaking reader. It is certainly not difficult to come by his works in the original or translations in the widely spread languages (mostly in Russian and more so in English). One of the main points of Nietzscheanism perception should be the use of common terminology by the Ukrainian researchers. However, what does the "Ukrainian Nietzscheanism" mean? Firstly, it is the reception of Nietzsche's philosophy in different spheres of the Ukrainian cultural being. The important thing is not just adequate reflection of these ideas but major coefficients of perception and realisation of these ideas: the objection, debate, methods of broadcasting, the level of discussion and understanding, finally, the prerequisites for the emergence of this discourse in Ukraine. Let us consider why the situation is as it is, and how Nietzsche has been seen by Ukrainian humanities.

If we need to select a starting point for reception of Nietzsche in Ukraine, I would choose an article by Kyiv based philosopher Ihor Bychko. This particular article was written in the 90ties, and still was one of the first, quite late, researches of the subject. The reason for that was the fact that Nietzsche studies were illegal in the Soviet Union, presented as a part of Nazi ideology. Bychko's article was titled Nietzsche in Ukraine [Бичко 1994], it drew almost radical parallels but understood their methodological supporting character. The author depicts Nietzsche as a figure of the German culture who embraced over 200 years of tradition of Western European Age of Enlightenment and offered anti-rationalistic, anti-mechanistic, existential program. Bychko focuses on the proximity of the Ukrainian and German mentalities, though he mentions its relativity. So what does it entail?

(C) Т. Лютий, 2017 
Formation of the western spiritual life is determined by the rationalist and classified coordinates, which are engraved in the naturalistic program of the Enlightenment. Instead, Ukrainian culture has long been leaning towards Hellenistic-Byzantine paradigm, focusing on dialectical, existential, irrational and mystical motives, aimed at the "inner" person. This is simply a scheme, but the real story is always more complicated. Thus, similar motifs were used by Augustine, Oxford and Chartres schools, and later - by Luther and Pascal. Western influence could be felt in Ukraine too, appearing in the principles of the educational process of Kyiv-Mohyla Academy. However, Germany (especially in the Middle Ages) experienced a particular situation: Areopagitica translated by Eriugena caught attention of Meister Eckhart, his work was picked up by the Rhine mystics and later by Jakob Böhme and Angelus Silesius. Later German romanticism intensified interest in the internal life of the individual. Therefore, the features of 'areopagitic' neoplatonism became Bychko's founding analogy (but not identity) between the German and Ukrainian mentality. The main feature of this mentality is apophatic with its denial of positive parameters of being and focuses on a personal way of the world's perception. For example, German-Ukrainian slavist and philosopher Dmytro Chyzhevsky showed common motifs in the works of the German mystics and pre-Ukrainian $18^{\text {th }}$ century philosopher Hryhoriy Skovoroda, whose mystical-existential mood can be seen in the works of mythological romanticism Ukrainian writers, such as Shevchenko and Gogol.

In continuation of Bychko's thoughts, I would stress that Nietzsche also used mythological thinking as opposed to scientific and dialectical. Nevertheless apophatic is not a neglectful denial but a kind of dialectical interconversion: negation and affirmation, something and nothing. Active nihilism is interpreted in a similar way: Nietzsche's revaluation of values is not a total reduction of being to nothingness, but getting rid of obstacles to affirmation of life. Conventionalism of the proposed interpretation is reflected in the Ukrainian perception of Nietzsche, which became noticeable in the early $20^{\text {th }}$ century. We are dealing rather with transformed forms of Nietzscheanism than with precise reflection of his doctrine. But the exact reconstruction would be less attractive. In addition, there were different degrees of response in German, Russian and Polish Nietzscheanism. The basis of this reception was the modern rise of Ukrainian nationalism (as it was the case with many other Eastern European groups).

Thus, Ukrainian cultural figures, who directly or indirectly accepted the concept of interrelation of power and dependency in human society and differences between values of the powerful and the dependent, focused on the use of Nietzsche's ideas in the cultural, historical, social and political perspectives. Let us see how this was happening by looking at some of the examples of the "Ukrainian Nietzscheanism".

\section{Literary and artistic vision}

Ukrainian researcher Solomiya Pavlychko [Павличко 1999] considers the "Ukrainian Nietzscheanism" as one of the central points in frames of the Ukrainian modernism at the end of the $19^{\text {th }}$ - beginning of the $20^{\text {th }}$ century. Nietzsche was declared to be one of the main inspirers of the arising movement, which spread philosophy of pessimism, decadence and moral criticism. This was strengthened by the increase in the number of translations, although the Ukrainian language was not powerful enough, as it was illegal 
to publish in Ukrainian. Generally, Ukrainian language was banned from the public use. Knowledge of Nietzsche's ideas tended to be trivial and unacceptable to the Democrat Populists, which was the major political position of most Ukrainian intelligentsia [ibid. 46-47]. One of the critics of the Literary and Scientific Journal, Yuriy Kmit (1901), considered works of Nietzsche a madness, extreme individualism and violation of common sense, anarchy in science, philosophy, ethics, religion [Кміт 1901]. Indeed, Nietzsche was the inspirer of the anti-populist theories. Nevertheless, one can see a distinctive paradox: Nietzsche's philosophy became an inspiration to conflicting philosophical and socio-political trends and movements, even those to which he was in opposition.

Hardly the first Ukrainian follower of Nietzsche was the $19^{\text {th }}$ century modernist writer Olha Kobylyanska. Her interest in Nietzsche was ahead of similar trends in the Russian literature. She grew up in Austro-Hungarian Empire with the German spirit and wrote her stories in German. She later created the image of a strong aristocratic heroine, who preferred to belong to the great and free people. This applies to the central ideology of her psychological work Tsarivna (Princess), but it is also a clear antithesis to Nietzsche’s anti-feminism. As Nietzsche said: "When going to a woman take the whip!"

Critics had various ratings of Tsarivna, given Kobylyanska's reference to the German thinker. According to another writer of that time and her friend Lesya Ukrainka, Kobylyanska's works show striving for the ideal of the superman [Гундорова 2009: 157-158]. While critic Osyp Makovey saw Nietzsche's “good influence”, because he taught her to look at people from a higher point of view [Маковей 1963]. Orientalist and writer Ahatanhel Krymsky was surprised that the author, while defending women's rights, admired the philosopher who was famous for his anti-feministic aphorisms [Кримський 1963]. Critic Serhiy Yefremov believed that Kobylyanska's heroes neglected their community duties [Сфремов 1995: 428-429]. Amazingly, Soviet literary criticism that never mentioned Nietzsche without its ritual cursing, acknowledged his influence on Kobylyanska, but it was considered to be brief [Павлишин 2008: 78-80].

An icon of Ukrainian early Socialist movement and also poet and philosopher Ivan Franko showed his disrespect to Nietzsche. He reproached Kobylyanska for being taken with decadent modernism [ibid. 67-68]. Franko considered many of modernist famous figures unrelevant, as they did not propose efficient (for him as a left oriented writer) solutions for social stigma. In fact, his thoughts carry a conflict between two understandings of modernization - according to Auguste Comte on the one hand, and Nietzsche on the other [Грицак 2005]. After all, Franko's opinion of Nietzsche as “correct” and Kobylyanska's as “false” became dominant in the Ukrainian humanities for many years (1920-90) [Лубківська 1995; Луців 1975]. His thoughts are that she copies single phrases from Nietzsche's works only to increase her vocabulary. On the other hand, he talks about her lack of understanding of the depth of Nietzsche's symbols and presentation of the German thinker's concept through the prism of her own outlook.

It is assumed with a great deal of probability that Kobylyanska knew well Thus Spoke Zarathustra, since she introduces a lot of quotes in her novel Vin $i$ Vona (Him and Her), where the refrain is repeated: “A man is something that must be overcome”. She knew Twilight of the Idols (quotes in Tsarivna echoed criticism of the European culture and religion). However, she gets to know his works more after 1895, when Kobylyanska 
reads The Men and Works by Georg Brandes with a chapter on Nietzsche and Untimely Meditations. Among Nietzsche's motifs in Kobylyanska's works, we can mention a superman, imperative of victory over self, the image of the Noon as a symbol of blossoming of the human potential, the "higher man" and the "man of the crowd" and so on. At the same time, the writer ridicules direct perception of Nietzscheanism. One can see controversy with Nietzsche in her works: it concerns the concept of resentment (ressentiment) as anger, combined with envy. In Tsarivna she rehabilitates ressentiment - insult, anger and pain often become a heroine's desire for revenge, which the author approves of. Kobylyanska's Nietzscheanism shows she was a part of the European intellectual space, it signifies human hopes and unrest, while declaring pessimistic image of reality [Павлишин 2008: 84-85, 95, 133-135, 142].

Lesya Ukrainka commented on her attitude to Nietzsche as negative [Павличко 1999: 48]. Nevertheless, contemporary literary critic Solemea Pavlychko sees lack of Lesya Ukrainka's perfect understanding of Nietzsche's philosophy, represented in the kitsch image. Lesya Ukrainka called him the singer of amoralism and destroyer of values. Despite her negative attitude, traces of Nietzsche's aesthetic individualism can be felt in her anti-Christian critique Oderzhyma (The Possessed), V Katakombah (In the Catacombs) and his Dionysys concept echoes in Lisova Pisnya (Forest Song) and Orgiyi (Orgies) [Гундорова 2009: 156].

\section{Critical modernist manifestation}

In the early $20^{\text {th }}$ century, Nietzsche's popularity has grown in Western Ukraine, but his ideas were not studied thoroughly. We have to remember that what we know today as Ukraine was divided between Russian and Austro-Hungarian Empires. Nietzsche is rather seen as the creator of the superman than a messenger of basic human instincts. The display of polar populist social and aesthetic values and shallow ideas was scattered throughout the Ukrainian literature's first two decades. One can see a conflict between the individual, creative personality and the society in many works. For young modernists Nietzsche was a weapon against populism and ethnographic primitivism [Tarnawsky 1991]. In the article Moloda Muza (Young Muse) published in the early $20^{\text {th }}$ century [Луцький 1907] Ostap Lutsky, a representative of the Lviv literary group with the same name (1906-1909), outlines the problem of the coming cultural crisis [Павличко 1999: 127-128]. Bohdan Lepky, another member of the Young Muse also called for uniting Nietzsche, Ibsen and Maeterlinck with the traditions of the native culture.

Later on, the cultural principles of the Kyiv magazine Ukrainska Khata (Ukrainian Home) (1909-1914), were based on the idea that only an individual can change and guide the entire audience by a personal action or art. Thus, the nation needed leaders in consolidation and the elaboration of the political theory. However, here once again we have the above-mentioned paradoxical reception of the Nietzscheanism because Nietzsche's ideas were anti-nationalist.

The Ukrainian acquaintance with Nietzsche comes from the secondary sources: popular articles, essays, analytical commentaries, where his philosophy is not properly systematized. Artistic movement titled Young Poland (Młoda Polska covering roughly the years between 1890 and 1918) that was influential in Western parts of Ukraine can boast 
a deeper knowledge of the German philosopher, but even here, his ideas often remain not "well-read". Many believed that Nietzsche influenced his era not so much by his philosophical ideas as by his style [Яковенко 2006: 56, 69]. Interesting fact: Ukrainian prose writer and political activist Vasyl Stefanyk took an active part in the life of Young Poland and in 1900, he acted as a mediator between Nietzsche's sister and the publisher Naumann to obtain permission for a Polish translation of Thus Spoke Zarathustra [Стефаник 1954: 43-45].

Nietzsche's name appears a lot on the pages of the so-called national-antidemocratic Ukrayinska Khata (Ukrainian Home) magazine. Critic and politician Mykyta Sriblyansky (Shapoval) refers to the concept of transformation of Nietzsche's values, directing it against the mass culture forms. Nietzsche's philosophy gave the members of Ukrayinska Khata the ability to interpret ideas. Therefore Sriblyansky suggests the ideal of a modern man without recourse to the past, creating an allusion to the concept of the superman with the attributes of individual freedom, renunciation of the mass humanity, destruction of the old values, with the idea of the cultural excellence [Бабич 2002].

A vivid example of Nietzscheanism can be found in the works of another most important literary critic Mykola Yevshan (Fedyushka). In his critique, one can see the concept of creation of a new culture that is associated with the problem of the individual creative personality, which he perceived through the prism of Nietzsche's strong-willed superman. With this in mind, he criticizes lyrical prose, naturalism and emotional nature of literature [Свшан 1998]. While analyzing the works of the writer and "national symbol" Taras Shevchenko, he focuses on the spontaneous, anti-intellectual features which are typical for Nietzsche. Yevshan associates ability to comprehend one's own prophecy, see the tragedy of being and manifest the love for your own fate (amor fati) with the type of a new creator.

\section{Ideological manifestations}

Later on Ukrainian writer and soon after an outstanding politician Volodymyr Vynnychenko showed a more active and nihilistic approach to Nietzscheanism [Панченко 2000]. This applies first of all to his literary work, which was considered by his contemporary to be immoral and individualistic. Symbiosis of Nietzscheanism and socialism was condemned by the so-called Ukrainophiles (we could describe them today as ethnographic party) and the democrats of all sorts (such as critic Serhiy Yefremov or journalist and army general Symon Petlyura), in particular the novel Chesnist z soboyu (Honesty with oneself) (1910).

In 1913 Pavlo Khrystyuk's article V. Vynnychenko and F. Nietzsche [Христюк 1919] appears. The author insists that Vynnychenko perceives Nietzsche's thoughts "directly and roughly" because the Ukrainian culture of the time had not yet formed a deep understanding of the modern tradition of philosophizing. In his reception of Nietzsche, Vynnychenko sometimes fails to define new problems. It seems that Vynnychenko adopted some of Nietzsche's thoughts and tried only to paraphrase them with the help of his heroes, rather than realize them in the artistic types. Therefore, Vynnychenko's Nietzscheanism mostly resulted in caricature depiction of the heroes. Perhaps Nietzsche 
remained to be only a detonator in this reception, which allowed explosion of completely other forces.

Let us move on from the theory of socialist individualism to the conservative ideology, where Nietzsche's influence becomes more radical in comparison to modernist criticism. This can be seen in the views of Vyacheslav Lypynsky whose writing was crucial for Ukrainian pre-war conservatists. One of his main views was a denial of egalitarianism. As a defender of the so-called “ploughman's ideology”, Lypynsky reveals its dominants in feeling the difference and hierarchy. Moreover, this ideology needs its leaders [Липинський 1998a: 123]. This type of a leader had clear signs of a nobleman (spiritual aristocrat) and showed brave chivalry nature. Lypynsky's conservative views include criticism of democracy, deprived of authority. The image of a strong man shows similarity with Nietzsche’s ideal of power [Липинський 1998b: 201].

Direct references to Nietzsche as the mastermind can be found in the works of the founder of the Ukrainian integral nationalism, Dmytro Dontsov. He sets his position as the principal anti-intellectualism. While making a distinction between nationalism and populism, he assimilates them to aggression and passivity, faith and knowledge, dogmatism and relativity. Comparing provincial nationalism and ideology, Dontsov sets off humanity, tolerance, solidarity, mutual love and uses plenty of Nietzsche's terms like "plebs". Lesya Ukrainka becomes an example of the strong-willed outlook with a philosophy of action, cruelty, rights of the strong [Донцов 2006: 73].

Although Dontsov did not develop a philosophical system, his thoughts were directed at identifying the core of decline, elimination of which would allow the Ukrainian nation to stay afloat in the global political turbulence of life. Dontsov was mostly attracted to Nietzsche's ideal of a superman with the will to power, and this ideal guided Dontsov in developing his ideal of the strong man who would be united in the "will to live" and the “will to power”. Nietzsche’s concept of morality and his ethical philosophy helped Dontsov in defining "immorality" as the basis "of the current nationalism”.

In the 1920s Ukrainian writers-immigrants of the Prague school sometimes managed to transform such nationalist spirit, and at the same time avoid populism and direct attention to the cultural issues. Their ideological guidelines met the challenges of the tragic reality (historical and that of civilization). Members of the Prague school did not oppose themselves to the non-individual crowd (unlike members of the Ukrainian Khata). They cultivated intellectual inspiration. Thus, through Dontsov's outlook but beyond his romantic and dogmatic passionarity, writer Yevgen Malanyuk adopts Nietzsche's aesthetic judgments. He complements the militant Dionysianism with prudent Apollonianism, while shifting the accents towards the arts [Маланюк n. d.].

At the time, Ukraine saw the introduction of the literary and artistic trends that corresponded to both elements. The first - represented by the futurism of Mykhayl' Semenko, who personified the type of the strong-willed "iron man" with a nihilistic art platform. Echoes of the image of the superman (leader of the masses) from the position of national-communism are depicted in the works of another writer - Mykola Khvyliovyj. While Nietzsche's love of life is riddled with motives of saving the European culture from lowlying pseudo-values, Khvyliovyj accumulates this same problem into taking care of his homeland [Смельянова 2008: 158]. 
The second one is intellectual neoclassicism with slow rhythms, pauses, silence. For example, Maxym Rylskyj reinterprets Nietzsche as a thinker who turns into an inner companion, not a persistent destroyer. In his collection of poems Synya Dalechin' (Blue Remoteness) (1922), the poet dedicated a sonnet to the philosopher. It is full of shining apollonian colors [Рильський n. d.]. This was a distinctive feature of the intellectual prose of those times. Valerian Pidmohyl'nyi's heroes tend to have a desire to theorize, and the mention of Nietzsche has added value [Pidmohyl'nyi 2006]. Like Nietzsche, Pidmohyl'nyi is skeptical about the achievements of the civilization that has made people more sophisticated, but still left a lot of the animal nature [Смельянова 2008: 159].

Many Nietzsche's motifs can be found in Victor Domontovych's novels. His heroes' opinions about their exclusivity, the self-search, affirmation of anti-moralism can be interpreted as a transformation of Nietzsche's motto "become the one who you are" [Белімова 2003].

In the Soviet Ukraine any researches of Nietzscheanism became increasingly dangerous, even those of the ideological views. This can be evidenced by Petro Demchuk's study on the analysis of Nietzsche's works and those of his followers [Демчук 1929; 1930]. In the article The philosophy of fascism (on the Philosophy of Life by Leopold Ziegler), he traced the origins of Nietzscheanism. Probably this was one of the grounds to blame him of uncritical approach to the understanding of the theory and practice correlation. In 1937 he was taken to the concentration camp and shot as a "representative of the Ukrainian national-fascism”. Therefore, while mentioning Nietzsche's name in the Soviet ideological system one had to use a number of "tags": reactionary idealistic movement, apologia of social inequality, exploitation of a man by a man, preaching war and vandalism, zoological hatred of the working masses, etc. [Куличенко 1982].

\section{Summaries}

The spreading and perception of Nietzsche's legacy in Ukrainian culture are no less complicated than understanding of his philosophy elsewhere in the world. At the very beginning the most common thing we can summarize in Western (German, French, British, Spanish or even Polish) and Ukrainian traditions is that there is no appropriate way to understand Nietzsche. He remains as a most ambivalent thinker. Since Nietzsche himself often defined his philosophizing as unclear for comprehension, in this article I have tried to explicate the different fluctuations in reception of his thoughts. In case of Ukrainian reception, we deal not with the direct tracing of his concepts, but with transformation and adaptation of certain Nietzsche's ideas. As consequence, some of these ideas are getting unexpected forms and ideological connotations.

In Ukraine, as well as in Germany, with some exception, there were not many eager readers of Nietzsche's works. However, in mid 1890s the situation changed extremely. Since that time, his name became very famous in literary and artistic fields. On the other hand, academic philosophers appointed to the substantial gap in his systematic exposition. Even today, one can find Nietzsche's name among others intellectual arrogants such as de Sade or Max Stirner.

Nevertheless, the most significant elements in Ukrainian reception were connected to the literary vision of Nietzscheanism. Acquaintance with some of Nietzsche's works 
provoked a huge desire of literary revival of sensuality and instinctive forms of human being. However, as we have seen, Nietzsche's ideas had many opponents even after his death. Sometimes even corrupt morality of the philosopher as a reflection of his perverted nature was mentioned. Since Nietzsche's main works were not translated into Ukrainian, this philosopher never became an influential figure in Ukrainian culture. As a result, he was reduced to no more than an inspirer of anti-populistic theories, which was not mainstream tendency at the end of nineteenth century. At the same time, the name of Nietzsche was associated with a flashy paradox - his philosophy determined almost all conflicting philosophical and socio-political trends and movements, including those that he himself opposed. Ukrainian authors who tended towards socialism did not give any positive interpretation to Nietzsche's philosophical views and their Ukrainian reception either.

Ukrainian Nietzscheanism started as one of the key points of Ukrainian Modernism in late nineteenth - early twentieth century. Nietzsche was announced as one of its main inspirers together with the philosophy of pessimism, decadence and moral criticism. In the result, Nietzsche's name received significant attention, but his philosophy still was not studied deeply.

In the early twentieth century, Nietzsche was very popular in Western Ukraine. However, it was no more than banal coping from Polish or German publications into new context. Nietzsche was classified as the creator of Superman (Overman) without critical perception. Ukrainian perception was formed by secondary sources, including popular articles, essays, analytical comments, where his philosophy was not systematized enough.

The main topics of Ukrainian Nietzscheanism concerned 'historical nihilism' as diagnoses of culture through the metaphor of 'empty space'. The notion of the 'death of God' as a marginal situation of man was also very significant. Nietzsche's thoughts became a powerful tool in critical approach to lyrical prose, naturalism, emotional writing and provincialism. It is important to emphasise that Nietzsche was frequently mentioned with no specific references to his works, and without direct quotations.

More significant nihilistic manifestations of Nietzscheanism were developed in literary works of Ukrainian socialist writers whose texts include elements of immoralizm, individualism, socialism and Nietzscheanism. However, Ukrainian individualistic Nietzscheanism is also represented in conservative and nationalistic ideology. It became more radical in comparison with the modernist critics. For instance, the concepts of 'immorality', 'master morality' and 'slave morality' are in the core of 'integral nationalism' that was developed in Ukrainian immigrant intellectual community before the World War II.

In addition, the concept of 'Dionysian culture' became an influential metaphor in Ukrainian futurism that was personified by the type of strong-willed 'iron man' of a nihilistic artistic platform in the third decade of twenty century. And a similar image of Superman resembled a leader of the masses in the National Communism.

To summarize, what does the 'Ukrainian Nietzscheanism' entail? The important characteristics that represent the ideas of Nietzscheanism in Ukraine include:

- $\quad$ the desire to find a strong man;

- $\quad$ the problem of individual freedom and its place in a society; 
- criticism of obscurantism;

- $\quad$ understanding of the critical moments in history;

- openness to interpretation and discussion;

- diagnosis of the cultural conditions;

- re-evaluation of the role of morality and religion;

- $\quad$ awareness of the tragedy of being;

- $\quad$ the actualization of creativity;

- the search for a balance between intelligence and voluntarism.

However, there are still concerns about the following factors: caricature and superficial nature and lack of analysis; insufficient study of the sources; selectiveness, the use of disparate characteristics and concepts; focusing mainly on the style, not the ideas; paradoxical combination of socialism, communism, and nationalism with Nietzscheanism.

\section{СПИСОК ЛІТЕРАТУРИ}

Бабич, С. (2002). Діалектика «порожнього місця»: рецепція культурної давнини в українському модернізмі. Слово і час, 6, 8-15.

Белімова, Т. В. (2003). Дискурс Ф. Ніцше як один із дискурсів тексту роману Віктора Домонтовича «Дівчина з ведмедиком». Вісник. Літературознавство. Мовознавство. Фольклористика, 14, 7-11.

Бичко, І. (1994). Ніцше в Україні. Філософська і соиіологічна думка, 9-10, 154-177.

Грицак, Я. (2005, 25 серпня). Франко - поза течією, маргінал, а тому революціонер. Розмова 3 Ярославом Грицаком. Львівська газета, 151(717). Отримано з http://iteratura.kh.ua/ person.php?idart $=44 \& i d=18$

Гундорова, Т. (2009). ПроЯвлення Слова. Дискусія раннього українського модернізму. Київ: Критика.

Демчук, П. (1929). Нариси про сучасний стан німецької філософії. Прапор марксизму, 6, 63-77.

Демчук, П. (1930). Нариси про сучасний стан німецької філософії. Прапор марксизму, 1-2, 17-28.

Донцов, Д. (2006). Ідеологія чинного націоналізму. In О. Проценко, \& В. Лісовий (Упоряд.), Націоналізм: Антологія (сс. 69-75). Київ: Смолоскип.

Євшан, М. (1998). Проблеми творчости. In М. Євшан, Критика, Літературознавство, Естетика (сс. 12-17). Київ: Основи.

Ємельянова, Н. М. (2008). Філософська рефлексія української інтелігенції (Доба «розстріляного відродження»). Вісник донецького університету, Серія Б: Гуманітарні науки, 1, 156-163.

Єфремов, С. (1995). Історія украӥнського письменства. Київ: Femina.

Кміт, Ю. (1901). Фрідріх Ніцше. In Літературно-науковий вісник, 8, 87-107.

Кримський, А. (1963). «Царівна». Оповідання Ольги Кобилянської. In Ф. П. Погребенник (Упоряд.), Ольга Кобилянська в критиці та спогадах (сс. 36-38). Київ: Держ. вид. худ. літ.

Куличенко, Л. К. (1982). Ніцшеанство. In М. Бажан (Ред.), Украӥнська радянська енциклопедія (Т. 7, с. 390). Київ: Гол. редакція УРЕ.

Липинський, В. (1998а). Мораль і політична дія. In О. Проценко, \& В. Лісовий (Упоряд.), Консерватизм: Антологія (сс. 196-201). Київ: Смолоскип.

Липинський, В. (1998b). Універсалізм у хліборобській ідеології. In О. Проценко, \& В. Лісовий (Упоряд.), Консерватизм: Антологія (сс. 120-132). Київ: Смолоскип. 
Лубківська, О. (1995). Моделі вияву ніцшеанської філософії в українській літературі. Сучасність, 4, 144-147.

Луців, Л. О. (1975). Кобилянська і Ф. Ніцше. In Л. Луців, Література і життя: Літературні оиінки (сс. 151-178). Джерсі Сіті: Свобода.

Луцький, О. (1907, 18 листопада). Молода муза. Діло.

Маковей, О. (1963). Ольга Кобилянська (Літературно-критична студія). In Ф. П. Погребенник (Упоряд.), Ольга Кобилянська в критииі та спогадах (сс. 44-67). Київ: Держ. вид. худ. літ.

Маланюк, Є. (n. d.). Книга спостережень. Франко незнаний. Одержано 17 жовтня 2016, 3 вебсайту Українське життя в Севастополі: http://www.ukrlife.org/main/evshan/ malaniuk2.htm

Павличко, С. (1999). Дискурс модернізму в українській літературі. Київ: Либідь.

Павлишин, М. (2008). Ольга Кобилянська: прочитання. Харків: Акта.

Панченко, В. (2000). Творчість Володимира Винниченка 1902-1920 pр. у генетичних і типологічних зв'язках з європейськими літературами. Одержано 5 листопада 2016, з вебсайту Електронна бібліотека ОНБУ Кіровоград: http://library.kr.ua/books/panchenko/ index.shtml

Рильський, М. (n. d.). Ніцше. Одержано 5 листопада 2016, з вебсайту Бібліотека кошового писаря: http://pysar.net/virsz.php?poet_id=58\&virsz_id=11

Стефаник, В. (1954). [Лист] 26. До В. I. Морачевського. In В. Стефаник, Повне зібрання творів: у 3-х тm. (Т. 3, сс. 43-45). Київ: ВАН УРСР.

Христюк, П. В. (1913). Винниченко і Ф. Ніцше. Украӥнська хата, 4-5, 275-299.

Яковенко, С. (2006). Романтики, естети, ніщщеаниі. Українська та польська літературна критика раннього модернізму. Київ: Критика.

Pidmohyl'nyi, V. (2006). A Little Touch Of Drama. Retrieved October 19, 2016, from Electronic Library of Ukrainian Literature website: https://www.yumpu.com/en/document/view/ 11517461/valerian-pidmohylnyi-a-little-touch-of-drama-university-of-toronto

Tarnawsky, M. (1991). Modernism in Ukrainian Prose. Harvard Ukrainian Studies, 15(3-4), 263-272.

Одержано 21.11.2016

\section{REFERENCES}

Babych, S. (2002). Dialectic of 'Empty Place': Reception of Ancient Culture in Ukrainian Modernism. [In Ukrainian]. Slovo i chas, 6, 8-15.

Belimova, T. (2003). F. Nietzsche's Discourse as One of the Discourses of the Text of Victor Domontovych' Novel "The Girl with the Teddy Bear”. [In Ukrainian]. Visnyk. Literaturoznavstvo. Movoznavstvo. Folklorystyka, 14, 7-11.

Bychko, I. (1994). Nietzsche in Ukraine. [In Ukrainian]. Filosofska i Siciolohichna Dumka, 9-10, 154-177.

Demchuk, P. (1929). Essays On the Modern German Philosophy. [In Ukrainian]. Prapor marksysmu, 6, 63-77.

Demchuk, P. (1930). Essays On the Modern German Philosophy. [In Ukrainian]. Prapor marksysmu, $1-2,17-28$.

Dontsov, D. (2006). The ideology of Actual Nationalism. [In Ukrainian]. In O. Protsenko, \& V. Lisovy (Eds.)., Nationalism: Antolohia. Kyiv, Smoloskyp.

Hrytsak, Y. (2005, August 25). Franko - out current, marginal, and therefore revolutionary. [In Ukrainian]. Lvivska hazeta, 151(717). Retrieved from http://iteratura.kh.ua/ person.php?idart $=44 \& i d=18$ 
Hundurova, T. (2009). Appearance of the Word. Discussion on Early Ukrainian Modernism. [In Ukrainian]. Kyiv: Krytyka.

Khrystiuk, P. (1913). V. Vynnychenko i F. Nietzsche. [In Ukrainian]. Ukrainska Khata, 4-5, 275-299.

Kmit, Y. (1901). Friedrich Nietzsche. [In Ukrainian]. Literaturno-naukovyj visnyk, 8, 87-107.

Krymsky, A. (1963). "Tsarivna". The story of Olga Kobylianska. [In Ukrainian]. In F. P. Pohrebennyk (Ed.), Olha Kobylianska in criticism and memories (pp. 36-38). Kyiv: Derz. vyd. khud. literatury.

Kulychenko, L. K. (1982). Nietzscheanism. [In Ukrainian]. In M. Bazhan (Ed.), Ukrainian Soviet Encyclopedia (V. 7, p. 390). Kyiv: URE.

Lubkivska, O. (1995). The Models of Manifestation of Nietzsche’s Philosophy in Ukrainian Literature. [In Ukrainian]. Suchasnist, 4, 144-147.

Lutsiv, L. (1975). Kobylianska and F. Nietzsche. [In Ukrainian]. In L. Lutsiv, Literature and Life: Literary Assessments (pp. 151-178). Jersey City: Svoboda.

Lutsky, O. (1907, November 18). Young Muse. Dilo.

Lypynsky, V. (1998a). Moral and Political Action. [In Ukrainian]. In O. Protsenko, \& V. Lisovy (Eds.), Konservatyzm: Antolohia (pp. 196-201). Kyiv: Smoloskyp.

Lypynsky, V. (1998b). Universalism in tilling ideology. [In Ukrainian]. In O. Protsenko, \& V. Lisovy (Eds.), Konservatyzm: Antolohia (pp. 120-132). Kyiv: Smoloskyp.

Makovey, O. (1963). Olha Kobylianska (Literary and Critical Study). [In Ukrainian]. In F. P. Pohrebennyk (Ed.), Olha Kobylianska in criticism and memories (pp. 44-67). Kyiv: Derz. vyd. khud. literatury.

Malaniuk, Y. (n. d.). The Book of Observation. Franko Unknown. [In Ukrainian]. Retrieved October 17, 2016, from Ukrainske gitt’a v Savastopoli website: http://www.ukrlife.org/main/ evshan/ malaniuk2.htm

Panchenko, V. (2000). Creation of Volodymyr Vynnychenko 1902-1920 in Genetic and Typological Relations to European Literatures. [In Ukrainian]. Retrieved November 5, 2016, from Electronna biblioteka ONBU Kirovograd website: http://library.kr.ua/books/ panchenko/index.shtml

Pavlychko, S. (1999). The Discourse of Modernism in Ukrainian Literature. [In Ukrainian]. Kyiv: Lybid.

Pavlyshyn, M. (2008). Olha Kobylianska: Reading. [In Ukrainian]. Kharkiv: Akta.

Pidmohyl'nyi, V. (2006). A Little Touch Of Drama. Retrieved October 19, 2016, from Electronic Library of Ukrainian Literature website: https://www.yumpu.com/en/document/view/ $\underline{11517461 / v a l e r i a n-p i d m o h y l n y i-a-l i t t l e-t o u c h-o f-d r a m a-u n i v e r s i t y-o f-t o r o n t o ~}$

Rylsky, M. (n. d.). Nietzsche. [In Ukrainian]. Retrieved November 5, 2016, from Biblioteka koshovogo pysaria website: http://pysar.net/virsz.php?poet_id=58\&virsz_id=11

Stefanyk, V. (1954). Letter 26 to V. I. Morachevsky. [In Ukrainian]. In V. Stefanyk, Complete collection of works: in 3 vol. (Vol. 3, pp. 43-45). Kyiv: VAN URSR.

Tarnawsky, M. (1991). Modernism in Ukrainian Prose. [In Ukrainian]. Harvard Ukrainian Studies, 15(3-4), 263-272.

Yakovenko, S. (2006). Romantics, aesthetes, nietzscheans. Ukrainian and Polish Literary Criticism of Early Modernism. [In Ukrainian]. Kyiv: Krytyka.

Yefremov, S. (1995). The History of Ukrainian Literature. [In Ukrainian]. Kyiv: Famina.

Yemelianova, N. (2008). Philosophical Reflection on Ukrainian Intellectuals (The Age of Executed Renaissance. [In Ukrainian]. Visnyk donetskoho universytetu, Seria B, 1, 156-163.

Yevshan, M. (1998). The Problem of Creation. [In Ukrainian]. In M. Yevshan, Krytyka; Literaturoznavstvo. Estetyka (pp. 12-17). Kyiv: Osnovy.

Received 21.11.2016 


\section{Taras Lyuty}

\section{Ideological Interpretations of Nietzsche's Philosophical Views in the Ukrainian Cultural Context (the end of the $19^{\text {th }}$ - beginning of the $20^{\text {th }}$ centuries)}

The paper states that, in Ukrainian reception of his philosophy, Nietzsche appears to be a highly ambivalent thinker. Nietzsche himself often defined his philosophizing as ambiguous, and so in this article I try to explicate the different fluctuations in the reception of his ideas. I follow the transformation and adaptation of some of Nietzsche's key ideas which, in Ukrainian context, got unexpected formulations and ideological connotations. Drawing on this, I argue that most significant elements in the Ukrainian reception are connected to the literary reading of Nietzscheanism. Finally, the main topics of Ukrainian Nietzscheanism are related to 'historical nihilism' as a diagnosis of culture. The article traces how Nietzsche's ideas became a powerful tool in critical approach to naturalism, emotional writing and provincialism. The important characteristics that developed the ideas of Nietzscheanism in Ukraine include the following points. The desire to find a strong man (Kobylyanska, Vynnychenko, Semenko). The problem of individual freedom and its place in society, as well as the criticism of obscurantism (Ukrainska Khata). The understanding of the critical moments in history and actualization of creativity (Khvyliovyj, Rylskyj). The openness to interpretation, discussion, and diagnosis of the cultural conditions (members of the Prague school). The re-evaluation of the role of morality and religion, the awareness of the tragedy of being and finally, the search for the balance between intelligence and voluntarism (Lypynsky, Dontsov).

Taras Lyuty, Doctor of sciences in philosophy, Associate Professor, Professor of the Department of Philosophy and Religious studies at the National university of 'Kyiv Mohyla academy.

Тарас Лютий, доктор філософських наук, доцент, професор кафедри філософії та релігієзнавства НаУКМА.

Тарас Лютый, доктор философских наук, доиент, профессор кафедры философии и религиоведения НаУКМА.

e-mail: febry@ukr.net 